\title{
THEORETICAL AND METHODOLOGICAL PRINCIPLES OF OPERATION OF THE JUSTICE BODIES OF UKRAINE
}

\section{Predmestnikov O. H.}

\section{INTRODUCTION}

The development of Ukraine as a modern European law-governed state implies the solution of many organizational and legal problems, in particular those related to the real assertion of the rule of law and ensuring the social orientation of the state, the development of national legislation and its harmonization with the law of the European Union, full and timely enforcement of court decisions, strict observance of citizens' rights in penitentiary institutions, accessibility and reliability of the provision of administrative services for state registration. The leading role in solving these and other relevant tasks is played by the justice authorities of Ukraine - an integral subsystem of executive authorities, which comprehensively provides for the formation and implementation of state legal policy, state policy in the areas of notary, organization of enforcement of decisions, execution of criminal penalties, bankruptcy registration and other similar issues.

Today, the Ukrainian judiciary authorities continue to be at a transitional stage of their institutionalization and implementation of the European experience of management in the field of justice and other related industries, in particular the positive tendencies towards elimination of unnecessary administrative units in the system of justice bodies of Ukraine, reduction of the number of employees, introduction of up-to-date electronic services, as well as the liberalization, decentralization and demonopolization of the relevant areas of activity of the Ukrainian justice authorities. At the same time, the effective activity and successful improvement of the status of the Ministry of Justice of Ukraine and its territorial bodies are significantly hampered by the imperfection, disorderliness and fragmentation of their administrative and legal bases, the absence of comprehensive and detailed legislative regulation of organizational, functional, personnel and financial institutions.

Adoption of the Law of Ukraine "On the Bodies of Justice of Ukraine", ensuring the coherence of legislative, subordinate and departmental regulation, its compliance with the urgent needs and tasks of the bodies of justice, as well as the real implementation of administrative legislation will contribute to the systematic nature of the bodies of Justice of Ukraine, their organization, purposefulness and liability to control. 
The analysis of the results of the previous scientific researches of the problems of the administrative and legal principles of operation of the bodies of justice of Ukraine reveals the lack of a single agreed and holistic understanding of the essence, significance and prospects of the development of regulation of the administrative and legal relations in the sphere of organization and operation of the bodies of justice of Ukraine for the effective implementation of state legal policy and other tasks of the justice authorities of Ukraine.

The need to improve the organization and operation of the Ukrainian justice authorities, the uncertainty of the concept and place of justice in the state mechanism of Ukraine, the nature and features of the administrative and legal regulation of the activity of the Ukrainian justice bodies determine the urgency of a thorough and comprehensive study of the administrative and legal foundations of the activity of the Ukrainian justice bodies.

\section{The concept and place of justice in the state mechanism of Ukraine}

Successful fulfillment of the tasks and functions of the state first and foremost requires the formation and functioning within the state mechanism of the relevant professional competent bodies of state power, responsible and specially empowered to carry out public administration in certain areas. One of such state bodies is the Ukrainian justice authorities, which are responsible for a number of important areas of governmental activity, in particular for the formation and implementation of state legal policy.

At the same time, in the process of their formation, the judicial authorities have repeatedly changed the status, powers, forms and methods of their implementation, which in the conditions of building a democratic rule of law in Ukraine today also require further substantial changes. At the same time, the experience of somewhat inconsistent institutionalization of justice bodies and fragmented administrative and legal regulation of their status reveal a lack of a comprehensive understanding of the nature and place of justice bodies in the state mechanism of Ukraine, which in general may adversely affect the performance of the tasks and functions assigned to them.

It should be noted that some issues of understanding the nature and importance of justice bodies have already been discussed in the works of such scientists as M.V. Gorbachev, O.S. Gusareva and O.D. Tikhomirov, N.A. Zheleznyak, S.O. Kozulin, I.I. Mikulets, O.V. Fedkovich and others. At the same time, such studies mainly reflect some aspects of the nature and legal status of justice bodies, without comprehensively revealing a coherent and consistent understanding of justice authorities as specific bodies of state power, especially taking into account the organization of the current system of justice bodies of Ukraine. Therefore, in the context of improving the status and 
increasing the efficiency of the functioning of the justice bodies of Ukraine, the issues of their concept and place in the state mechanism of Ukraine are seen as topical.

First of all, it should be noted that a comprehensive characterization of the nature and place of the bodies of justice of Ukraine requires consistent establishment of the content of the concepts "body", "justice" and "state body", disclosure of the structure of the state mechanism, definition of the legal nature, system and role of justice bodies as bodies of state (executive ) authorities. Here, first of all, it should be noted that, in the general lexical sense, "authority" can often be identified with "institution" and "organization" and is generally defined as "an institution that performs certain functions in the field of public administration, control, supervision, etc. $»^{1}$. In other words, the main features of the "body" (state, international organization, party, commercial structure, etc.) are its organizational integrity and isolation (autonomy), as well as its own competence (powers, united by common goals).

The concept of justice, based on its name, is closely linked to justice, which is a complex multidimensional phenomenon that is not understood at the regulatory level and differs not only in scientific sources but also in countries with different legal systems. In particular, justice is seen as justice; the totality of the judiciary and their activities; procedure for dispute resolution and resolution; a legal institute whose activities are aimed at securing the rule of law and the law. Obviously, identifying justice only with justice and/or the judiciary can be justified except in a historical and legal context. At present, this is a very narrow and limited approach to understanding this phenomenon, which leaves open the question of the relation with the Justice of the Ministry of Justice of Ukraine and its bodies, which according to the Constitution of Ukraine of 28.06.1996 do not belong to the judicial system of Ukraine and do not administer justice.

More constructive is the broad understanding of justice as a system of courts and other institutions connected with their activity, which are intended to serve the rule of justice, law and justice, and the protection of citizens' rights. The definition of I.Yu. Onnopchuk justice as a sphere of activity of the state aimed at prevention, detection and elimination of violations of law in order to ensure the realization of citizens' rights, affirmation of justice and lawfulness (which actually equates justice and law enforcement activity). On the one hand, these definitions, unlike the above definitions, justifiably emphasize the organizational affiliation with the justice of other (except courts) bodies and the functional focus of justice not only on the administration of justice, but also on the general protection of the rights and interests of citizens and the state, the organization of the courts' activities, legal policy, etc. 
But on the other hand, such a definition of justice appears too abstract and indeterminate, which implies, on a somewhat artificial basis, a number of institutions that are distinctive in nature at the same time. Thus, in addition to judicial institutions, the notion of justice also includes the Ministry of Justice and its bodies, bodies of the prosecutor's office, investigators, notaries, attorneys, the execution of sentences and other bodies engaged in various law enforcement, law enforcement and law enforcement activities. Attribution of these bodies to justice O.S. Gusareva, first of all, explains the focus of their joint activity on "ensuring the real implementation of the ideal of justice." However, in today's democratic rule of law, by this criterion, the vast majority of state bodies can be classified as justice, which will undoubtedly be incorrect and will only complicate the understanding of justice as a legal phenomenon. It should be noted that the activities of the prosecution, investigation and advocacy bodies are indeed closely related to the administration of justice, but substantially different from it and generally have a law enforcement character, which actualizes the definition of these bodies not only as bodies of justice, but as law enforcement agencies.

Today, in our opinion, the Ministry of Justice of Ukraine and its bodies should be regarded not as subjects of direct justice and fairness, which consider and resolve disputes (such as courts and other quasi-judicial bodies), but as subjects (bodies) of public administration in the field of justice. A similar position is taken by I.Yu. Onopchuk and Yu.S. Shemshuchenko, designated by the Ministry of Justice as the governing body in the field of justice, which organizes the work of relevant institutions in the administration of justice and law and order in the country; In turn, V.K. Kolpakov reveals the essence of public administration in this area as the executive activity of authorized entities in the organizational support of the functioning of courts, public notaries, bodies of record of civil acts, judicial expert institutions and organizations of lawyers. In general, while agreeing with the above, we should make it clear that the content of public administration in the field of justice is not limited to ensuring the activities of relevant human rights and law enforcement agencies and institutions, but also includes other independent activities, such as the formation and implementation of state legal policy. However, in a democratic rule of law, the Ministry of Justice and its bodies are not "justice" management bodies, but "in the field of justice", which emphasizes the rather broad subject matter of the Ministry of Justice and its bodies and their non-interference with the practical work of courts and other review bodies and dispute resolution.

The bodies of justice, represented by the Ministry of Justice of Ukraine and its territorial bodies, are formed and maintained by the state, and their activity is directed to fulfill the tasks of the state to ensure the rule of law, justice and rights of citizens. The above points to the state nature of the 
Ministry of Justice of Ukraine and its bodies, which first of all updates the definition of the place of justice bodies in the state mechanism and their essence as respective institutions (bodies) of the state.

It should be noted that at present, there is no unified established understanding of the concept and composition of the state mechanism, and therefore of its constituting state institutions. Yes, O.V. Rakul outlines three approaches to defining the state mechanism: as a way of functioning of state bodies; sequence of actions of state bodies, the process of implementation of state power by them; as a system of state bodies, institutions and organizations united to fulfill the functions of the state. In turn, L.R. Nalyvayko distinguishes the legal (legal foundations), structural (set of state organizations), functional (functions) and instrumental (powers, methods and methods of their implementation) components of the category "mechanism of the state". The identification of VF is quite interesting. Burning mechanism of the state with the structure of state power, which consists of state authorities and other state organizations, as well as regulatory, information, budgetary and territorial bases of state power. In our opinion, all these approaches complement each other, revealing a certain aspect of the state mechanism. The concept of the mechanism of the state comprehensively covers the relevant state institutions, the legal regulation of their status, as well as the competence, forms and methods of activity and practical fulfillment of their duties.

The activity of justice bodies is carried out on behalf of the state and in its interests, directly focusing on the implementation of political, law enforcement and other functions of the state, namely the implementation of state legal policy, public policy in the field of notary and organization of enforcement of decisions, on issues of state registration of civil status acts. etc. The state-power nature of the powers of the Ministry of Justice of Ukraine and its bodies is confirmed not only by their focus on the performance of the tasks and functions of the state, but also by the use of their legal and organizational forms and methods of activity, the obligation to execute orders (legal orders) of the bodies of justice provided different forms and means of state coercion. However, we have to disagree with the definition of a state body by M.Yu. Volyanskyy - the perception of their acts by members of society as state, since such a definition is too abstract, is purely subjective and does not reveal the objective nature and real organization of the activity of the respective state institution.

A feature of state bodies means a well-defined territorial basis of their activity. The Ministry of Justice of Ukraine, as the central executive authority, operates throughout Ukraine, the territorial offices of justice operate within the Autonomous Republic of Crimea, a specific region, Kyiv and Sevastopol, and interregional departments on criminal penalties and probation across several 
areas. Establishing the territorial scope of the activities of the justice authorities is an important component of the organization of their activities, connected with the rational distribution of powers and resources between the justice authorities, ensuring their interaction and subordination to the higher authorities.

It should be noted that the status of the Ministry of Justice of Ukraine and its territorial bodies as state bodies (state authorities) and their place in the state mechanism of Ukraine are directly related to the principle of division of the state system, which according to Article 6 of the Constitution of Ukraine of 28.06. 1996 manifests in the separation of legislative, executive and judicial branches of state power.

Within the division of state power, the affiliation of the bodies of justice to the legislative (represented only by the Verkhovna Rada of Ukraine) and judicial (represented by the courts) branches of state power is excluded. In addition to the legislative, executive, and judicial bodies, some scientists also distinguish other subsystems of state bodies, in particular O.V. Rakul and N.P. Kharchenko also single out the Head of State and the supervisory bodies. Based on the normatively defined competence of the justice bodies of Ukraine, control and supervision do not constitute the leading direction of their activity, which does not allow to attribute the bodies of justice to the number of control and supervisory bodies.

Based on the general understanding of the state body (state authority) and summarizing the main essential features of the executive body, it can be defined as a state body with administrative (executive-administrative) powers in economic, socio-cultural and administrative-political area.

The organization and activity of the bodies of justice of Ukraine is governed by the norms of various branches of law, but mainly by administrative and legal norms, which is conditioned by their status of bodies of executive power and implementation of administrative (executiveadministrative) activity, its specific forms and methods.

The signs of the executive authorities should also include the certainty of their organization and activity solely by the laws of Ukraine, which is expressly provided for in paragraph 12 of Part 1 of Art. 92 of the Constitution of Ukraine of 28.06.1996. Today, the status of executive bodies, in particular the bodies of justice of Ukraine, is regulated mainly by by-laws (for example, the Regulation on the Ministry of Justice of Ukraine, approved by the Cabinet of Ministers of Ukraine dated 02.07.2014, No. 228) . In this regard, we believe that the feature of the executive authorities should be not the exclusivity, but the complexity and detail of the legislative consolidation of their status with its further specification at the by-law level, which will ensure real orderliness and stability of the organization of the justice bodies of Ukraine, coherence and efficiency of their functioning. 
As a sign of executive bodies I.I. Mykulets stipulates "the ability of executive authorities to take only those actions that are either expressly stated in the law or related to the need for its implementation." First of all, the statement does not fully correspond to the provisions of Part 2 of Art. 6, Part 2 of Art. 19 of the Constitution of Ukraine of 28.06.1996, which obliges the bodies of state (and not only executive) power to act only on the basis, within the powers and in the manner provided by the Constitution and laws of Ukraine. Therefore, contrary to current practice, these constitutional norms do not allow subordinate regulation of the powers of the judicial bodies, even in connection with such an abstract circumstance as "the need to comply with the law." Although, stating the need to eliminate such contradictions in constitutional norms and the practice of regulating the status of justice bodies, their activities are now subject not only to the law but also to the relevant by-laws.

It is possible to agree with a certain degree of conditionality on such a definition of executive bodies as "a special order of formation of these bodies and the appointment of their heads, scope and content of competence", since the formulation of this feature is too abstract and does not reveal the nature and specificity of the executive authorities. The competence of the justice bodies of Ukraine consists of by-laws of executive and administrative powers (normalization and enforcement), the volume and content of which is determined by the status and tasks of these state bodies. In particular, the justice authorities are endowed with the possibility of applying coercive measures, with broad and exclusive managerial powers in the field of justice and in other related fields, for the implementation of which they are directly responsible. The procedure for establishing justice bodies and appointing their heads also has a number of peculiarities, for example, the appointment of the Minister of Justice of Ukraine by Parliament upon the submission of the Prime Minister of Ukraine, the appointment of heads of the main territorial departments of justice by the State Secretary of the Ministry of Justice of Ukraine, etc. This specificity of the formation of justice bodies and the appointment of their leadership is, first of all, connected with the increased importance of the productive and lawful fulfillment of the tasks of the justice bodies, the need to ensure the coordinated functioning of all verticals of the executive bodies at the national and local levels.

Organizational and functional separation, as noted above, is one of the basic features of state bodies in general. The bodies of justice, as bodies of state executive power, are also characterized by organizational and functional independence from other state bodies, which is expressed in the presence of not only specific administrative powers and subjects of authority, but also their own structural organization, permanent staffs and guaranteed financial support. 
The judiciary of Ukraine is one of the leading actors in securing the development of Ukraine as a modern democratic, rule of law, social state and its integration into the European Union. Therefore, the modern organization of the progressive principles and principles of lawful, professional, transparent and responsible provision of the formation and implementation of the state's legal and other policy should be the basis for the organization and activity of the Ukrainian justice bodies. At the same time, the administrative and legal foundations of the status of the bodies of justice of Ukraine leave the initial baselines and standards of their functioning completely unregulated, which causes insufficient coherence, stability and rationality of organization and activity of the bodies of justice of Ukraine.

It should be noted that the purpose of the activity of the bodies of justice and their place in the state mechanism in the legal regulation are not specifically stated. At the same time, the tasks and powers of the justice authorities of Ukraine are in many ways similar, though somewhat broader than the appointment of law enforcement agencies. In particular, as noted above, the administrative (executive-administrative) activity of the bodies of justice, first of all, is aimed at accomplishing the tasks of the state in strengthening the rule of law and justice, ensuring the realization of citizens' rights. In turn, O.I. Bakirova defines the mission of the Ministry of Justice of Ukraine as ensuring the democratic development of society "with the aim of strengthening human rights and freedoms through the implementation of the rule of law in the justice system." However, the given understanding of the mission (purpose) of the justice authorities appears to be not sufficiently welldefined and meaningful. Thus, instead of referring to the "democratic development of society", it would be more appropriate to speak about the focus of the activities of the bodies of justice on building a European democratic, social, rule of law, as well as ensuring the rule of law and citizens not only "in the justice system" (justice), but in other areas, for example, through the implementation of state legal policy.

The notion and place of justice in the state mechanism of Ukraine are closely related to understanding the purpose of their activity. Given the responsibility, size and complexity of the powers of the justice authorities, it is appropriate to identify the immediate and ultimate purpose of their activities. Therefore, the immediate purpose of the activity of the justice bodies of Ukraine is the formation and implementation of state legal policy, state policy in the field of notary, organization of enforcement of decisions, execution of criminal penalties, bankruptcy and state registration and other similar issues; and the ultimate goal is to promote the rule of law and justice, to ensure the realization and protection of the rights and legitimate interests of citizens and legal persons, public and state interests, the formation of the rule of law and civil society. 
In addition to the above said purpose of activity, the special importance of justice bodies in the state mechanism is primarily determined by their status and traits as state bodies (bodies of state power) and bodies of executive power exercising public administration (executive and administrative powers) in the field of justice and in other related fields. The place of justice bodies in the state mechanism is determined by the fact that they are the subjects of public administration in the administrative and political sphere, constitute a coherent and separate subsystem of executive bodies responsible for the implementation and ensuring the formation of the legal and other policies of the state. The system of justice bodies in Ukraine and in other countries, at level with the systems of law-enforcement and foreign-affairs bodies, constitute an indispensable basis for the executive power and the state mechanism as a whole.

The main distinguishing feature of the Ministry of Justice of Ukraine is also the variety of objects of its state administration, which include the territorial departments of justice, courts, notary offices, advocacy, associations of citizens, other central executive bodies. The objects of the administrative activity of the justice bodies are quite a large number of state institutions, institutions, public formations and citizens themselves, which is mainly determined by the above-mentioned broad nature of the executive and administrative powers of the justice bodies to implement the legal and other policies of the state. At the same time, as for us, the diversity of public administration objects is an important, but not exclusive, feature of the bodies of justice, which is peculiar to some other bodies of executive power, for example, the Ministry of Internal Affairs of Ukraine, whose administrative powers are similarly related to those who are different in nature. and the status of subordinate bodies of the executive power, other state and municipal bodies, institutions and organizations, public formations and citizens.

\section{The essence and features of the administrative and legal regulation of the activity of the bodies of justice of Ukraine}

In Ukraine, as a modern rule of law, the status and organization of the activity of the justice bodies of Ukraine (as well as other state bodies) should be clearly regulated by the current legislation. The legality and efficiency of the implementation of the state legal policy and the fulfillment of other tasks of the bodies of justice, as well as the observance of human rights and freedoms in their activity, directly depend on the completeness, coherence and consistency of administrative and legal support. At the same time, at the level with the problem of practical implementation of the current administrative and legal foundations of the organization and activity of the bodies of justice of Ukraine (caused by a large number of legal acts and their inadequate quality), there is also a lack of complex legislative regulation of their status, 
fragmentation, contradiction and lack of consistency ensuring the systematic and functioning of the Ukrainian justice authorities.

In the scientific literature, legal regulation is generally defined as the implementation by the system of legal means of effective, regulatory and organizational influence on public relations for the purpose of their ordering, protection and development. At the same time, legal regulation is not only a direct and powerful legal influence on public relations, but also its form. One way or another, we have to agree with O.F. Skakun that the essence of legal regulation lies not only in the ordering, protection and development of relevant relationships, but also in their legal expression and consolidation (and according to M.S. Kelman and O.G. Murashin - also in ensuring relations). In particular, the general purpose and content of administrative and legal regulation of the functioning of the justice bodies of Ukraine, as a means of legal influence on relations in the sphere of their organization and activity, should determine the legal expression, ordering, protection and development of such relations. In this way, the interests of the state, society, its individual parts and citizens are satisfied, as well as ensuring the proper functioning of state and public institutions, the behavior of all subjects of law in accordance with the rule of law.

In doing so, I.I. Mykultsya sees the purpose of legal regulation of the activity of the justice bodies of Ukraine in ordering such activity and ensuring its development within the normatively determined limits and directions. This can indeed be attributed to the objectives of legal regulation of the activity of the justice authorities, which at the same time requires some clarification and detail. Thus, administrative and legal regulation in general aims to formulate the proper conditions and rules for the organization of the bodies of justice of Ukraine and productive fulfillment of their tasks and functions. In our opinion, understanding of the purpose of administrative and legal regulation of functioning of justice bodies of Ukraine is directly connected with the purpose of their activity.

Equally important is the issue of the mechanism of legal regulation - a set of legal instruments that directly influence the normative and organizing influence on public relations, which consist of the formation and functioning of justice bodies of Ukraine. It should be emphasized here that, in a broad sense, administrative regulation is not limited to legal norms alone, although they, with appropriate binding rules of conduct, represent the main legal means of influencing public relations (which take some legal form).

The essential interdependent components of the administrative and legal regulation of the activity of the bodies of justice of Ukraine are both qualitative rulemaking and the precise and steady practical implementation, observance and application of the rules of law, which together provide the reality of the legal regulation of the functioning of the justice bodies of 
Ukraine. In turn, the real reflection of legal principles in the organization and activity of justice bodies is a basic criterion for the effectiveness of administrative and legal regulation of their status.

It should be noted that the method of administrative and legal regulation represents the set of appropriate methods and methods of legal influence on public relations in the sphere of organization and activity of the bodies of justice of Ukraine. For the administrative and legal regulation of the functioning of the bodies of justice of Ukraine as a whole, a common administrative law (imperative method of authority) based on legal inequality and subordination of legal entities is peculiar to administrative law. In particular, this method is manifested in a clear legal definition of the tasks, powers, structural organization and management vertical of the justice bodies of Ukraine, the procedure, methods and framework for their implementation of relevant areas of management (registration, control, organizational and other) activities. Advantages of applying the imperative method of administrative and legal regulation (mostly prescriptions and prohibitions) is a high level of orderliness of organization and coherence of the activity of the whole network of bodies of justice, legality and unambiguity of power orders and promptness of their implementation.

At the same time, the development and democratization of public administration actualize the application in administrative and legal regulation of the activity of state bodies (including the bodies of justice) at the level of the imperative as well as the dispositive method. The value of the dispositive method (which is expressed, for example, through the granting of authorizations) is manifested, first of all, in the equality of legal entities, their greater degree of autonomy in the choice and use of certain legal remedies. Today, due to the increased complexity and responsibility of the functions of the bodies of justice of Ukraine, the dispositive method in regulating their organization and activity is applied to a limited extent, in particular with regard to the formation and operation of the collegium and other subsidiary bodies of the Ministry of Justice of Ukraine, the intensity and content of interaction with public authorities and the public, definition of a specific management model in the body of justice, etc.

Among the special methods of regulating the functioning of the justice bodies of Ukraine should also be mentioned subordination, coordination, coordination, administrative contract, etc. Subordination is the starting point for the organization of the entire public administration apparatus, including the system of justice bodies, which provides for the vertical subordination of the lower bodies (officials) to the higher ones and ensures the uniform, accurate and prompt execution of administrative decisions by all justice bodies, their departments and employees. Equally important is the coordination that underlies the interaction and coordination of the joint activity of the justice 
authorities with directly subordinate public authorities (for example, the coordination of the territorial departments of justice with the activities of local executive authorities on the systematization of legislation). In the activity of justice bodies there is also coordination, one of the visual manifestations of which is the right of citizens (managed object) to demand certain behavior of justice bodies (managing entity), which, in turn, are obliged to respond to the legitimate demands of citizens ( on state registration of civil status acts, public formations, etc.), creating the proper conditions for the exercise of their rights and interests. The use of administrative treaties, the conclusion of which may help to regulate the relations of the justice bodies with other public authorities, remains promising in regulating the activity of the justice authorities.

The legal bases of functioning of the bodies of justice of Ukraine are represented by a considerable number of various international legal, constitutional, legislative and subordinate legal acts, which directly establish the legal status, rules and conditions of organization and functioning of the system of justice bodies of Ukraine as a whole and its individual components.

Regarding the international legal principles of the functioning of the justice bodies of Ukraine, first of all, it should be noted that the subject of their regulation is the conceptual bases of the organization of the activity of the state bodies (and therefore the justice bodies) and the international legal aspects in certain areas of activity of the Ukrainian justice bodies. Thus, the bodies of justice, as well as any other authorities empowered by the authorities, must in their activity observe and contribute in every way to the implementation of international legal acts that determine fundamental human rights and their guarantees, - the Universal Declaration of Human Rights of 10.12.1948, Convention on the Protection of Human Rights and Fundamental Freedoms of 04.11.1950, International Covenant on Civil and Political Rights of 16.12.1966 and others.

The Constitution of Ukraine of 28.06.1996 is also one of the key sources of legal regulation of the functioning of the bodies of justice of Ukraine. The status of the bodies of justice of Ukraine is not directly regulated at the constitutional and legal level, however, the general rules on organization of activity of state bodies and executive authorities (in particular, apply) their orientation and coordination are determined by the Cabinet of Ministers of Ukraine and the procedure for appointing ministers). The integrity of the state apparatus and the proper performance of the state's functions are facilitated by the extension of the constitutionally defined principles of the separation of state power, legality, rule of law, observance of citizens' rights (for example, to associations in public formations, to participation in public affairs management, to legal aid) etc.

The norms of the Constitution of Ukraine, acting as the basis of administrative legislation in the sphere of functioning of the bodies of 
justice of Ukraine, have enhanced legal force, stability and correctness. Even a side mention in Part 3 of Art. 131 of the Constitution of Ukraine the Minister of Justice of Ukraine makes it impossible to abolish this position or to liquidate the Ministry of Justice of Ukraine, but at the same time the Basic Law allows any reorganization by the Cabinet of Ministers of Ukraine. That is why, at the constitutional level, the basics of legal status and the initial principles of organization and activity of the justice bodies of Ukraine should be prioritized.

You should also agree with P.M. Kikot here that the Constitution of Ukraine by its legal nature and purpose cannot provide comprehensive legal regulation of the activities of ministries and other executive bodies, including the bodies of justice of Ukraine. On this basis, a detailed regulation of the administrative and legal status of justice bodies is updated by a separate legislative act. The latter is supported by the provisions of Part 2 of Art. 6, Part 2 of Art. 19, item 12 part 1 Art. 92, part 2 of Art. 120 of the Constitution of Ukraine, which directly stipulate not the by-law (as it is today), but the legislative definition of the organization, powers and order of activity of bodies of executive power, and, consequently, of bodies of justice of Ukraine.

The administrative legislation that defines the organization and activity of the justice bodies of Ukraine consists of a number of legislative acts concerning either the general aspects of the functioning of the bodies of state (executive) power, or certain areas of practical activity of the bodies of justice. In the absence of a profile law of Ukraine on the organs of justice, the basic Laws of Ukraine "On Central Executive Bodies" of 17.03.2011 No. 3166-VI and "On the Cabinet of Ministers of Ukraine" of 27.02.2014, No. 794-VII are important in the legislative regulation of the activity of the Ministry of Justice of Ukraine and its territorial bodies and set out the basics of the legal status of the ministries, their tasks and principles of relations with the government, the status and powers of the minister and his deputies, the organization of work of the apparatus, territorial bodies, colleagues and support of the ministry, the status of its orders and so on. Legislative regulation of these issues as a whole ensures the uniformity of construction of all central executive bodies, the coherence of their functioning and unified approaches to the management of the system of executive bodies of Ukraine.

At the same time, it should be borne in mind that the norms of the above-mentioned legislative acts regarding the organization of activities of central executive bodies are mainly of a general nature (eg, by taking a somewhat formal approach to formulating the principles and tasks of the ministries) and are rather fragmentary, deployed without regulating the status of territorial bodies ministries and leaving undetermined the principles of the ministries' relations with various public authorities. Moreover, such an approach to legislative regulation does not allow to fully take into account the 
specificities of the competence and internal organization of the Ministry of Justice of Ukraine and its territorial bodies.

At the same time, the legislative regulation of the principles of implementation of the leading directions of activity of the bodies of justice of Ukraine, directly related to important national interests and the realization of human and citizen's rights and freedoms, is quite reasonable and justified. In particular, it refers to the enforcement of registration powers by the bodies of justice on the basis of the Law of Ukraine "On State Registration of Civil Status Acts" of 01.07.2010 No. 2398-VI and others. The aforementioned legislative act contains a rather detailed legal definition of the powers of state registration bodies, the principles of keeping state registers, the procedure and features of state registration at its various phases and stages. Such an approach to legislative regulation allows to ensure the maximum regime of legality, efficiency, transparency and observance of the rights of citizens while performing the registration functions of the justice bodies of Ukraine on such fundamental issue as the status of individuals. The high level of legal regulation of registration functions by the bodies of justice is confirmed by the deepening of the provisions of administrative legislation in departmental legal acts, for example, the rules of state registration of civil status acts are also established by the Order of the Ministry of Justice of Ukraine dated December 24, 2010 No. 3307/5.

Currently, the legal regulation prevails in the administrative and legal support of the activity and organization of the justice bodies of Ukraine. Bylaw regulation really allows to define and modify legal bases more quickly and in detail both the functioning of the justice bodies of Ukraine as a whole, and their fulfillment by separate divisions of narrow tasks. At the same time, a large array of by-laws also reveals their instability, non-system and insufficient correctness, without excluding the existence of gaps in administrative and legal regulation.

In the Legal Regulation of the Activity of the Bodies of Justice of Ukraine I.I. Mykultsya identifies two main areas - regulation of organization of activity of the Ministry of Justice of Ukraine and its territorial bodies and regulation of their work in corresponding directions. According to the peculiarities of administrative and legal support of the functioning of the justice bodies of Ukraine, we should refer to a relatively high level of standardization and unification not only of the internal organization of the justice bodies and their designated divisions, but also of certain areas of their practical activity. 


\section{CONCLUSIONS}

The nature of the bodies of justice of Ukraine, represented by the Ministry of Justice of Ukraine and its territorial bodies, as subsystems of bodies of executive power and their place in the state mechanism is determined by the totality of the following features: status of bodies of executive power, accountability, subordination and control over higher bodies of executive power; systematic and hierarchical, organizational and functional independence, interconnectedness with other state bodies; activities on behalf of the state and in its interests; mainly administrative and legal regulation of organization and activity; clearly defined territorial basis of activity; enforcement and executive nature of the activity; implementation of day-today and operational public administration in the field of justice and other related fields; issuing mandatory instructions for the enforcement of various forms and means of state coercion; recruiting on a regular professional basis by civil servants; providing the state with the necessary organizational and material and financial resources, etc.

The immediate purpose of the activity of the justice bodies of Ukraine is the formation and implementation of state legal policy, state policy in the field of notary, organization of enforcement of decisions, execution of criminal penalties, bankruptcy and state registration and other similar issues. Such activity of the justice bodies of Ukraine should ultimately ensure the establishment of the rule of law, the formation of the rule of law and civil society, ensuring the implementation and protection of the rights and interests of citizens, legal entities, society and the state.

The institutionalization of the justice bodies of independent Ukraine is directly linked to the development of administrative and legal principles of their activity, which generally provide higher than before the level of by-law regulation of competence and separate directions of activity of the bodies of justice of Ukraine, while remaining haphazard and fragmentary; there has also been a controversial parallel regulation of the activity of the Ministry of Justice of Ukraine by the Head of State and the Government.

Administrative and legal regulation of the activity of the bodies of justice of Ukraine is a deliberate implementation by the authorized entities with the purpose of effective formation and implementation of the legal and other policy of the state by means of a system of legal means (administrative and legal norms, legal relations, acts of legal realization, etc.), protection and development of organizational-managerial relations in the sphere of organization and activity of justice bodies of Ukraine. The reality and effectiveness of the administrative and legal regulation of the activity of the justice bodies of Ukraine requires not only the completeness, coherence and consistency of rulemaking, but also the accurate and steady implementation, compliance and application of relevant legal rules in practice. 


\section{SUMMARY}

The concept and place of justice bodies in the state mechanism of Ukraine, historical and legal bases of their formation, principles of activity of justice bodies of Ukraine and features of its administrative and legal regulation are explained. The tasks, functions, powers and organizational structure of the Ministry of Justice of Ukraine and its territorial bodies, as well as the administrative and legal status of the Minister of Justice of Ukraine and the leadership of territorial bodies of justice are clarified.

It is stated that the bodies of justice, represented by the Ministry of Justice of Ukraine and its territorial bodies, are bodies of executive power, which, in accordance with the current legislation, exercise administrative powers aimed at the formation and implementation of legal and other state policies, in order to ensure the rule of law, justice and citizens' rights. In the study, a coherent understanding of the essence of the bodies of justice is a necessary condition for their systematic nature, which should not only underlie the administrative and legal status of the justice bodies of Ukraine, but also be reflected in their real organization and activity. It is stated that the absence, contrary to the requirements of the Constitution of Ukraine, of a profile law on the organs of justice of Ukraine and, as a consequence, the predominant regulation of the organization of their activities by a large number of different by-laws, is one of the main features of the administrative and legal support of the functioning of the bodies of justice.

It is established that the essence of administrative and legal regulation of the functioning of the bodies of justice of Ukraine lies in the legal expression, ordering, protection and development of organizationalmanagerial relations in the sphere of their organization and activity in order to effectively form and implement the legal and other policies of the state. The administrative and legal support of the activity of the bodies of justice of Ukraine is characterized, first of all, by the lack of the necessary complex legislative regulation of their status and the prevalence of by-laws (departmental) legal acts, which reveal haphazardness, lack of coherence and correctness, as well as the lack of a clear definition of the principles of systematicity and interaction and the procedure for exercising all their powers.

\section{REFERENCES}

1. Алфьоров С. М., Ващенко С. В. Адміністративне право. Загальна частина: навч. посіб. Київ: Центр учбової літератури, 2011. $216 \mathrm{c}$.

2. Бакірова О. I. Державно-правовий механізм забезпечення конституційного права людини і громадянина на судовий захист та місце органів юстиції України у здійсненні правосуддя. Бюлетень Міністерства юстиції України. 2007. № 7. С. 127-139. 
3. Великий енциклопедичний юридичний словник / за ред. Ю. С. Шемшученко. Київ: ТОВ «Видавництво «Юридична думка», 2007. 992 c.

4. Великий тлумачний словник сучасної української мови (з дод. i допов.)/уклад. і голов. ред. В. Т. Бусел. Київ; Ірпінь: ВТФ «Перун», 2005. 1728 с.

5. Волянський М. Ю. Щодо загального поняття органу держави (державного органу). Університетські наукові записки. 2006. № 1. C. 32-36.

6. Гусарєва О. С. Юстиція як складова правових систем сучасних країн світу та України: автореф. дис. ... канд. юрид. наук: 12.00.01. Київ, 2010. $16 \mathrm{c}$.

7. Железняк Н. А. Правові та організаційні форми діяльності Міністерства юстиції України у здійсненні державної правової політики (теоретичні та практичні питання): дис. ... канд. юрид. наук: 12.00.07. Київ, 2004. 258 с.

8. Железняк Н. А. Правові та організаційні форми діяльності Міністерства юстиції України у здійсненні державної правової політики (теоретичні та практичні питання): автореф. дис... канд. юрид. наук: 12.00.07. Київ, 2005. 21 с.

9. Кельман М. С., Мурашин О. Г. Загальна теорія держави і права: підручник. Київ: Кондор, 2006. 477 с.

10. Кикоть П. В. Міністерства в системі органів виконавчої влади України: автореф. дис. ... канд. юрид. наук: 12.00.07. Київ, 2002. 16 с.

11. Колпаков В. К. Адміністративне право України: підручник. 3-є вид., стер. К.: Юрінком Інтер, 2001. 752 с.

12. Микульця I. I. Адміністративно-правовий статус органів юстиції України: дис. ... канд. юрид. наук: 12.00.07. Харків, 2014. 203 с.

13. Наливайко Л. Р. Державний лад України: поняття, система, гарантії: автореф. дис. ... Д-ра юрид. наук: 12.00.01. Харків, 2010. 40 с.

14. Онопчук I. Ю. Конституційно-правові засади статусу Міністерства юстиції України в системі виконавчої влади. Правове регулювання економіки. 2009. № 9. С. 101-110.

15. Онопчук I. Ю. Юстиція: до визначення поняття. Правове регулювання економіки. 2008. № 8. С. 99-107.

16. Органи державної влади України: монографія / за ред. В. Ф. Погорілка. Київ: Ін-т держави і права ім. В. М. Корецького, 2002. $592 \mathrm{c}$.

17. Про затвердження Положення про Міністерство юстиції України: постанова Кабінету Міністрів України від 02.07.2014 № 228. Офіційний вісник України. 2014. № 54. Ст. 1455. 
18. Про затвердження положень про територіальні органи Міністерства юстиції України: наказ Міністерства юстиції України від 23.06.2011 № 1707/5. Офіційний вісник України. 2011. № 49. Ст. 1984.

19. Ракул О. В. Теоретичні засади удосконалення діяльності державного апарату України: автореф. дис. ... канд. юрид. наук: 12.00.01. Київ, 2010. 17 с.

20. Скакун О. Ф. Теорія держави і права: підручник. 2-ге вид. Харків: Консум, 2005. С. 488.

21. Стеценко С. Г. Адміністративне право України: навч. посіб. Київ: Атіка, 2008. 624 с.

22. Харченко Н. П. Поняття механізму держави, наукові пошуки теоретико-правової дефініції. Ученые записки Таврического национального университета им. В. И. Вернадского. Серия «Юридические науки». Т. 20 (59). № 2. 2007. С. 278-284.

23. Шестопалова Л. М. Теорія держави і права: навч. посібн. Київ: Прецедент, 2006. 197 с.

24. Юридична енциклопедія: в 6 т./редкол.: Ю. С. Шемшученко та ін. Т. 6. Т-Я. Київ: Українська енциклопедія імені М. П. Бажана, 2004. $765 \mathrm{c}$.

\section{Information about the author: \\ Predmestnikov O. H.,}

Doctor of law Sciences, Associate Professor, Professor at the Department of Professional and Special Disciplines, Kherson Faculty of Odessa State University of Internal Affairs 1, Fonvizina str., Kherson, 73000, Ukraine 